\title{
PERAN GURU DALAM MEWUJUDKAN TUJUAN PEMBELAJARAN PENDIDIKAN AGAMA ISLAM DI SEKOLAH
}

\author{
Tatang Hidayat ${ }^{1}$, Makhmud Syafe'i ${ }^{1}$ \\ 1Program Studi Pendidikan Agama Islam Sekolah Pascasarjana Universitas Pendidikan Indonesia \\ tatanghidayat@upi.edu \\ makhmud@upi.edu
}

\begin{abstract}
The purpose of this study is to determine the role of teachers in realizing the objectives of Islamic Religious Education learning in schools. This present study employed a qualitative approach in the form of literature study. Based on the results of the study, the learning objectives of Islamic Religious Education were easily featured by the integration between the life of the world and the hereafter. Therefore, the Islamic Religious Education learning plans should be formulated in a different method compared to other subjects. In the learning processes of Islamic Religious Education, teachers were highly encouraged to be skillful in developing learning materials and methods. Accordingly, as the role of teachers, they were firstly encouraged to understand the pedagogical competence. Based on the material aspects, teachers were encouraged to have ability in developing Islamic Religious Education materials not only in the realms of cognitive understanding but also in the realms of practical good deeds. In addition, based on the methodological aspects, teachers were encouraged to courageously utilize Islamic education methods, such as the methods of Quranic education, riyadhah, rihlah, talaqi, halaqah, and many more. With respect to the learning evaluation, teachers were encouraged to assess the aspects of the attitudes and skills of students on a daily basis in practicing Islamic teachings since it is obvious that the essence of the objectives of learning Islamic Religious Education was to realize faithful, knowledgeable, and pious students.
\end{abstract}

Keywords: Pedagogical Competence, Islamic Religious Education, Learning Objects, Schools, Teachers 


\begin{abstract}
ABSTRAK
Tujuan penelitian ini adalah untuk mengetahui peran guru dalam mewujudkan tujuan pembelajaran Pendidikan Agama Islam di sekolah. Penulisan ini menggunakan pendekatan kualitatif dengan jenis studi literatur. Berdasarkan hasil pembahasan, tujuan pembelajaran Pendidikan Agama Islam memiliki ciri khas terintegrasi antara kehidupan dunia dan akhirat, sehingga dalam merumuskan perencanaan pembelajaran Pendidikan Agama Islam mestinya harus berbeda dengan mata pelajaran lain. Dalam proses pembelajaran Pendidikan Agama Islam, guru mesti terampil dalam mengembangkan materi dan metode pembelajaran, maka disinilah peran guru mesti memahami kompetensi pedagogik. Ditinjau berdasarkan aspek materi, guru mesti mampu mengembangkan materi Pendidikan Agama Islam bukan hanya dipahami dalam pengetahuan, tetapi materi tersebut harus mampu membuahkan amal perbuatan. Adapun ditinjau berdasarkan aspek metode, guru mesti mulai memberanikan diri menggunakan metode yang berasal dari pendidikan Islam, seperti metode pendidikan Qurani, metode Riyadhah, metode rihlah, metode talaqi, metode halqah dan yang lainnya. Dalam evaluasi pembelajaran, guru mesti menilai aspek sikap dan keterampilan peserta didik sehari-harinya dalam mengamalkan ajaran Islam, karena hakikat tujuan mempelajari Pendidikan Agama Islam untuk mewujudkan peserta didik yang beriman, berilmu, dan beramal.
\end{abstract}

Kata kunci: Guru, Kompetensi Pedagogik, Pendidikan Agama Islam, Sekolah, Tujuan Pembelajaran

\title{
Pendahuluan
}

Proses pendidikan sebagai upaya dalam mengembangkan potensi manusia di dalamnya ada yang dinamakan proses pembelajaran. Sebelum melakukan proses pembelajaran, seorang guru mesti mempersiapkan segala sesuatunya mulai dari perencanaan, merumuskan tujuan, mengembangkan materi dan metode hingga dengan evaluasi pembelajaran. Dalam merencanakan pembelajaran didalamnya ada yang dinamakan tujuan pembelajaran, tujuan pembelajaran sangat penting untuk dirumuskan karena akan dijadikan acuan dalam menentukan keberhasilan pembelajaran. Di sisi lain, tujuan pembelajaran dapat digunakan sebagai pedoman dan panduan saat proses pembelajaran dilakukan. Tujuan pembelajaran dapat digunakan juga sebagai acuan untuk mengembangkan desain pembelajaran. Oleh karena itu, proses pembelajaran mesti dilakukan untuk mewujudkan tujuan pembelajaran, hal demikian berlaku juga dalam proses pembelajaran Pendidikan Agama Islam (PAI). 
Hidayat \& Syafe'i (2018) mencatat mata pelajaran PAI memiliki tugas mengembangkan potensi peserta didik dalam menanamkan nilai-nilai keimanan, ketakwaan dan akhlak mulia sebagaimana yang tercantum dalam Undang-Undang No 20 tahun 2003. Oleh karena itu, disinilah pentingnya perencanaan pembelajaran PAI dibuat, supaya dalam mengajarkan mata pelajaran PAI bisa efektif dan efisien. Implikasinya, guru PAI mesti membuat sebuah perencanaan pembelajaran yang bisa mengembangkan potensi manusia menuju manusia yang mulia, yakni manusia beradab, cerdas dari sisi intelektual, sehat, dan memiliki keahlian yang memadai bukan manusia yang setelah lulus belajar orientasinya hanya materi.

Ada hal yang menarik dalam merumuskan tujuan pembelajaran mata pelajaran PAI khususnya dalam Rencana Proses Pembelajaran (RPP), tujuan tersebut akan sangat berbeda dengan mata pelajaran lainnya. Oleh karena itu, idealnya dalam penyusunan RPP mata pelajaran PAI mestinya berbeda dengan mata pelajaran lain. Dikatakan demikian karena penyusunan RPP mata pelajaran PAI cakupan tujuannya tidak hanya semata-mata mencakup aspek pengetahuan, tetapi harus juga mencakup aspek sikap dan keterampilan. Sementara itu, penggunaan pendekatan, metode, teknik, taktik, dan model pembelajaran pun mesti ada ciri khas tersendiri dibandingkan dengan mata peajaran lainnya.

Namun dalam kenyataannya di beberapa sekolah sebagaimana ditemui oleh penulis, ternyata dalam penyusunan RPP yang dilakukan oleh guru PAI rata-rata belum menyusun RPP dengan melihat beberapa aspek ciri khas mata pelajaran PAI. Salah satunya masih banyak ditemukan beberapa guru PAI yang menyusun RPP sama dengan mata pelajaran lain, bahkan dari tahun ke tahun RPP yang dibuat hampir sama dengan tahun sebelumnya. Padahal telah kita pahami bersama bahwa keadaan psikologis peserta didik setiap tahunnya mengalami perbedaan, oleh karena itu rumusan RPP pun mestinya mengalami pengembangan.

Beberapa problematika yang ada dalam penyusunan RPP PAI tentunya disebabkan oleh beberapa hal, diantaranya masih minimnya teori berkaitan dengan pengembangan RPP dalam mata pelajaran PAI, masih minim juga literatur yang menjelaskan mengenai metode pembelajaran Islam, belum optimalnya peran guru dalam mewujudkan tujuan pembelajarna PAI, dan belum ditemukan alat evaluasi yang efektif da efisien dalam mengevaluasi mata pelajaran PAI yang merujuk ranah pengetahuan, sikap, dan keterampilan (Hidayat \& Kosasih, 2019).

Problematika dalam penyusunan RPP PAI ini tentunya akan menjadi hambatan dalam proses pembelajaran jika tidak ditemukan solusi dalam memecahkan problematika tersebut. Disinilah pentingnya suatu pengkajian untuk menyelesaikan salah satu penyebab problematika penyusunan RPP PAI di sekolah. Dari sekian banyak 
penyebab yang ada, belum optimalnya peran guru dalam mewujudkan tujuan pembelajaran PAI di Sekolah menarik kiranya untuk diselesaikan.

\section{Metode Penelitian}

Hidayat \& Asyafah (2018) meneliti bahwa jenis-jenis metode penelitian Islam terdiri dari metode bayani, burhani, tajribi, dan 'irfani. Pertama, metode bayāni yaitu suatu metode penelitian untuk menemukan ilmu dengan usaha maksimal membaca, mempelajari, memahami dan mengkaji penjelasan-penjelasan dari naș-naș Alquran dan Hadis. Kedua, metode burhāni yakni suatu metode penelitian yang mengandalkan kemampuan berfikir logis dengan kaidah-kaidah tertentu secara runut dan sistematis. Ketiga, metode tajribi yakni suatu metode penelitian selain memerankan kemampuan berfikir logis juga dilanjutkan dengan tindakan eksperimen, observasi dan bentukbentuk metode yang dikenal dengan metodologi ilmiah seperti kualitatif, kuantitatif dan metode campuran antara keduanya. Keempat, metode 'irfāni yaitu suatu metode penelitian yang mengandalkan mendekatkan diri kepada Allah Subhānahu Wa Ta'ālâ dengan melakukan langkah-langkah tertentu mulai dari isti'dad hingga tazkiya

Dalam penelitian ini, peneliti menggunakan menggunakan pendekatan kualitatif dengan jenis penelitian studi literatur yakni dengan mencari referensi teori yang relevan dengan permasalahan yang ditemukan. Cara pengambilan data dengan mencari referensi dari berbagai sumber berupa buku, jurnal, hasil seminar dan hasil diskusi dengan beberapa ahli yang relevan dengan tema penelitian. Adapun analisis data dalam penelitian ini dengan metode analisis deskriptif, yakni dilakukan dengan mendeskripsikan fakta-fakta yang ditemukan, kemudian disusul dengan analisis yang tidak semata-mata menguraikan, melainkan penulis juga memberikan pemahaman dan penjelasan secukupnya.

\section{Hasil dan Pembahasan}

Dalam merencanakan pembelalajaran, seorang guru mesti menguasai terlebih dahulu aspek-aspek yang ada dalam perencanaan pembelajaran. Tim Pengembang Ilmu Pendidikan FIP-UPI, Ilmu Dan Aplikasi Pendidikan III (2007:316) dalam Fathurrohman \& Nurhadi (2016) memaparkan bahwa dalam perencanaan pembelajaran terdapat aspek psikologis, aspek pedagogis, aspek manajerial, dan aspek kontinuitas. Yang dimaksud dengan aspek psikologis yakni seorang guru yang terampil membuat perencanaan pembelajaran dan setia membuatnya akan memiliki rasa percaya diri dan keberanian. Aspek pedagogis disini adalah dalam perencanaan pembelajaran akan mendidik guru 
untuk disiplin dan berusaha untuk meningkatkan wawasannya. Aspek manajerial, yakni dengan perencanaan pembelajaran yang akan dilaksanakan akan menjadi terarah, sehingga tujuan yang diharapkan akan tercapai. Sedangkan aspek kontinuitas, yakni perencanaan pembelajaran akan menjamin adanya keseimbangan, baik dalam kelancaran kegiatan belajar mengajar maupun materi pembelajaran.

Berdasarkan kompetensi yang harus dimiliki oleh pendidik, maka tidak berlebihan dikatakan bahwa tugas menjadi seorang guru bukanlah tugas yang mudah, namun mesti memiliki keterampilan tersendiri apalagi saat ini menjadi guru sudah menjadi profesi. Salah satu keterampilan yang harus dikuasai guru adalah keterampilan membuat perencanaan pembelajaran, karena hal demikian akan mempengaruhi terlaksananya proses pembelajaran bahkan sampai evaluasi pembelajaran.

Perencanaan membuat pembelajaran berlangsung secara sistematis, melalui perencanaan yang baik, maka pembelajaran tidak akan berlangsung seadanya, tetapi akan terarah dan terorganisir dan guru dapat memanfaatkan waktu seefektif mungkin untuk mencapai tujuan pembelajaran. (Bararah, 2017). Oleh karena itu, sebelum melakukan proses pembelajaran seorang guru harus membuat perencanaan pembelajaran dengan sebaik-baiknya, salah satunya dengan membuat RPP.

\section{Desain Pembelajaran}

Sebelum menentukan desain pembelajaran, seorang guru mesti merumuskan tujuan pembelajaran terlebih dahulu supaya memudahkan dalam merencanakan desain pembelajaran. Hidayat \& Suryana (2018) mencatat dalam konteks PAI, tujuan pembelajaran tidak hanya mencakup aspek aqliyah, namun harus sampai kepada aspek qolbiyah dan amaliyah. Dalam hal ini aqliyah berbeda dengan kognitif, karena aqliyah urusannya berkaitan dengan aturan Allah Subhanahu Wa Ta'ālā. Begitupun dengan qolbiyah berbeda dengan afektif, sikap yang dilakukan mesti berdasarkan dengan perintah dan larangan Allah Subhanahu Wa Ta'ālā. Begitupun dengan aspek amaliyah berbeda dengan psikomotorik, keterampilan yang ada bukan hanya sekedar keterampilan semata, namun dalam pandangan PAI mesti membedakan, bahwa keterampilan yang ada juga mesti berdasarkan dengan perintah dalam larangan Allah Subhanahu Wa Ta'ālā.

Disinilah akan ditemukan ciri khas mata pelajaran PAI dengan mata pelajaran lainnya. Disini peran seorang guru mesti terampil dalam membuat RPP. Kualitas generasi muda bangsa bergantung pada pendidikan yang ditempuhnya. Pendidikan yang paling berpengaruh adalah pendidikan formal atau pendidikan sekolah. Apa yang hendak dicapai sekolah dari mulai mengembangkan ilmu pengetahuan, keterampilan, dan sikap peserta didik ditentukan oleh kurikulum yang ditetapkan sekolah tersebut (Chamanti, 
2013). Maka kurikulum yang dibuat di suatu negara akan mempengaruhi output sumber daya manusia negara tersebut, kurikulum yang biasa saja tentunya akan melahirkan peserta didik yang biasa juga.

Ditinjau berdasarkan kurikulum 2013, dapat dipahami bahwa didalamnya ada penekanan dalam aspek penilaian autentik (authentic assesment). Penilaian terhadap proses dan hasil pembelajaran merupakan bagian yang tidak dapat terpisahkan dari perencanaan maupun pelaksanaan proses pembelajaran guru. Adapun agar penilaian dapat dilakukan dengan baik perlu dilakukan secara autentik. Karena, penilaian autentik merupakan penilaian yang dilakukan secara komprehensif untuk menilai mulai dari masukan, proses, dan keluaran pembelajaran (Sya'idah, Amaliyah, \& Ismail, 2016).

Oleh karena itu, dalam kurikulum 2013 sebenarnya sudah cukup bagus dalam mengevaluasi pembelajaran peserta didik, karena keberhasilan pembelajaran peserta didik tidak hanya dievaluasi dari aspek hasil saja, namun dari proses pembelajaran pun dievaluasi dan ini selaras dengan konsep evaluasi PAI. Dalam mata pelajaran PAI ada beberapa aspek evaluasi yang justru banyak dilihat dari segi proses pembelajaran. Misalnya, guru mesti menilai peserta didik dalam aspek mengamalkan ajaran Islam seperti dalam shalat berjama'ah, shalat sunnah, berbuat baik sesama teman, menghormati guru, menghormati ilmu, jujur, tanggung jawab dan berbagai amal yang lainnya. Maka disinilah peran seorang guru mesti cerdas untuk melihat perkembangan peserta didik dalam kesehariannya. Apalagi dalam pendidikan Islam yang pertama ditekankan adalah adab bukan ilmu, maka seorang guru yang cerdas akan memberikan penilaian yang lebih kepada peserta didik yang adabnya baik daripada kecerdasannya.

\section{Peran Guru Dalam Mewujudkan Tujuan Pembelajaran PAI di Sekolah}

Sebelum menentukan perencanaan pembelajaran, pertama-tama perencana harus melihat ruang lingkup untuk bergerak yang dimiliki oleh para pembuat keputusan. Misalnya mereka harus melihat keadaan masyarakat, ke mana mereka akan pergi, dan apa yang akan dikehendaki melalui pendidikan dapat sampai ke tujuannya; mereka harus melihat juga sifat para peserta didiya, kebutuhan mereka, keinginan-keinginan, dan masa depan yang praktis; melihat keadaan pengetahuan itu sendiri, keadaan pendidikan seni dan teknologi, dan akhirnya melihat kemampuan sistem pendidikan yang ada, mengujinya secara kritis dan mengambil langkah-langkah yang bijaksana untuk meningkatkan hasil-nya. Salah satu tugas utama perencanaan pendidikan adalah menentukan bagaimana membuat hubungan antara faktor-faktor dalam dan luar dari sistem pendidikan ini sebaik mungkin sehingga menjadi sesuatu yang seimbang dan masuk akal dalam suasana perubahan yang dinamis serta menjalinkannya secara teratur menuju ke arah yang dikehendaki (Coombs, 1982:3). 
Tujuan dari perencanaan pembelajaran yakni sebagai pedoman guru dalam melaksanakan praktek mengajar. Dengan demikian apa yang dilakukan guru pada waktu mengajar bersumber kepada perencanaan pembelajaran yang telah dibuat sebelumnya. Rencana pembelajaran harus memperhatikan minat dan perhatian peserta didik terhadap materi standar yang dijadikan bahan kajian. Dalam hal ini, harus diperhatikan agar guru jangan hanya berperan sebagai transformator, tetapi harus berperan sebagai motivator yang dapat membangkitkan gairah belajar, serta mendorong peserta didik untuk belajar, dengan menggunakan berbagai variasi media, dan sumber belajar yang sesuai, serta menunjang pembentukan kompetensi dasar (Rohmah, 2008:28).

Dalam konteks pembelajaran PAI, perencanaan sistem pembelajaran PAI adalah suatu pemikiran persiapan untuk melaksanakan tujuan pengajaran melalui langkahlangkah dalam pembelajaran yang menjadi suatu kesatuan yang terdiri atas komponen atau elemen yang saling berinteraksi, saling terkait, atau saling bergantung membentuk keseluruhan yang kompleks menjadi kombinasi yang tersusun meliputi unsur-unsur manusiawi, material, fasilitas, perlengkapan dan prosedur yang saling mempengaruhi untuk mencapai tujuan pembelajaran PAI. Tujuan dan merumuskan serta mengatur pendayagunaan sumber-sumber daya: informasi, finansial, metode dan waktu yang diikuti dengan pengambilan kepustusan serta penjelasannya tentang pencapaian tujuan, penentuan kebijakan, penentuan program, penentuan metode-metode dan prosedur tertentu dan penentuan jadwal pelaksanaan program (Chamanti, 2013).

Pembelajaran PAI bertujuan untuk meningkatkan pemahaman, keimanan, penghayatan, dan pengamalan peserta didik tentang agama Islam, sehingga menjadi manusia muslim yang beriman dan bertakwa kepada Allah Subhanahu Wa Ta'ālā, serta berakhlak mulia dalam kehidupan pribadi, keluarga, dan masyarakat. Meskipun tujuan pembelajaran PAI belum terlaksana dengan ideal, namun setidaknya upaya ke arah sana sudah dilakukan. Oleh karena itu, mesti ada upaya alternatif yang dilakukan guru PAI dalam mewujudkan pembelajaran PAI yang orientasinya bukan hanya di kelas.

Berangkat dari hal ini, maka mesti ada metode lain dalam mewujudkan tujuan pembelajaran PAI supaya lebih efektif, salah satunya dengan metode riyadoh atau latihan dalam melakukan berbagai ibadah seperti shalat dhuha, membaca Alquran, melantunkan kalimat-kalimat thoyyibah, dibiasakan membaca hadis dan intinya bagaimana di sekolah tersebut ada rekayasa untuk menciptakan suasana religius yang tentunya harus melibatkan semua elemen yang ada di sekolah (Hidayat \& Suryana, 2018). Di sisi lain, bisa juga menggunakan metode pendidikan Islam di antaranya metode pendidikan Qurani, metode rihlah, metode halqah, metode talaqi, dan lain-lain (Hidayat, Rizal, \& Fahrudin, 2018b). 
Keberhasilan dalam proses pembelajaran tidak terlepas bagaimana seorang guru mengemas perangkat pembelajarannya, karena yang sangat mempengaruhi dan menentukan berhasil tidaknya pembelajaran yang dilakukan oleh seorang guru tergantung bagaimana menerapkan pendekatan yang dapat menunjang strategi, metode, dan kesesuaian materi yang akan diajarkan (Latif, 2015). Oleh karena itu, tugas guru PAI sebenarnya bukan hanya mencerdaskan saja, tetapi harus juga mewariskan kepribadian dan keteladanan kepada peserta didik, sehingga kepribadian guru PAI akan diteladani oleh peserta didik (Hidayat, Rahmat, \& Supriadi, 2019). Diantara peran guru PAI mesti hadir yakni saat menghadapi peserta didik yang mengalami kesulitan belajar, guru PAI bisa melakukan strategi dengan cara yang halus dan mudah dimengerti, yakni menggunakan tiga metode yaitu al-hikmah, maui'zah hasanah, dan mujādalah (Hidayat \& Rahmat, 2018).

Maka dari itu, disinilah peran guru PAI mesti menonjol di sekolah, karena pendidikan di sekolah saat ini tengah kehilangan sosok figur, salah satunya sosok figur guru PAI (Hidayat \& Syahidin, 2019). Dengan demikian, guru PAI mesti menjadi sosok figur dan rujukan peserta didik di sekolah dalam masalah apapun. Tatkala guru PAI sudah menjadi sosok figur, maka mata pelajaran PAI akan disenangi peserta didik daripada mata pelajaran lainnya. Dengan demikian, masuk mata pelajaran PAI tidak membosankan lagi, justru mata pelajaran PAI akan ditunggu-tunggu oleh peserta didik, dan itu tidak terlepas dari peran guru PAI yang menjadi sosok figur dan teladan di sekolahnya.

Setelah guru PAI menjadi sosok figur yang diteladani peserta didik, mulai dari sana guru PAI bisa menanamkan nilai-nilai adab kepada peserta didik. Salah satunya nilai yang telah hilang pada budaya sekolah saat ini yakni nilai menghormati guru dan ilmu. Hidayat, Rizal, \& Fahrudin (2018a) mencatat guru dalam pandangan Islam menempati posisi yang sangat mulia, guru merupakan wasilah sampainya ilmu kepada murid. Jika murid tidak menghormati dan memuliakan guru, maka murid tersebut tidak akan memperoleh ilmu dan mengambil manfaatnya. Oleh karena itu, nilai tersebut mesti dibangun kembali, jika sudah tertanam, maka akan ada keridhoan antara guru dan murid dalam proses pembelajaran.

Evaluasi dalam pembelajaran Pendidikan Agama Islam harus dilakukan secara komprehensif dan terintegrasi. Kedudukan evaluasi sangat penting dalam pembelajaran Pendidikan Agama Islam, karena evaluasi menempati posisi yang sangat sentral untuk mengetahui keberhasilan proses pembelajaran. Evaluasi dilakukan untuk mengetahui efektivitas dan efisiensi pembelajaran yang dilakukan, fungsinya untuk mengetahui kapasitas pendidik dan peserta didik, sehingga bisa dilakukan perbaikan jika memang ditemukan ada faktor yang belum optimal dalam proses pembelajaran. Kegunaan evaluasi dalam pembelajaran Pendidikan Agama Islam untuk perbaikan, penyesuaian, 
dan penyempurnaan program berdasarkan pengalaman pendidik yang didapatkan di lapangan. Prinsipnya harus kontinuitas, komprehensif, terintegrasi, adil, objektif, kooperatif, praktis, koherensi, dan akuntabilitas. Jenis evaluasinya mencakup evaluasi perencanaan, pengembangan, monitoring, efisiensi, dan program komprehensif (Hidayat \& Asyafah, 2019). Dengan demikian, guru mesti menilai aspek sikap dan keterampilan peserta didik sehari-harinya dalam mengamalkan ajaran Islam, karena hakikat tujuan mempelajari Pendidikan Agama Islam untuk mewujudkan peserta didik yang beriman, berilmu, dan beramal. Dengan demikian, buah dari peserta didik beriman, berilmu, dan beramal akan melahirkan karakter akhlak mulia.

Hidayat, Syahidin, \& Rizal (2019) mencatat karakter akhlak mulia tidak akan didapatkan manakala di dalam sistem pendidikannya tidak memfasilitasi untuk menuju ke arah sana. Oleh karena itu, diperlukan sistem pendidikan yang mampu memfasilitas untuk terwujudnya lulusan yang memiliki karakter akhlak mulia. Maka disinilah esensi diterapkannya sistem pendidikan Islam yang akan memfasilitasinya, karena akhlak tidak bisa lahir hanya dengan proses pembelajaran saja, tetapi memerlukan pemikiran, perasaan, dan aturan hidup sama yang diterapkan dalam sistem pendidikan.

\section{Simpulan}

Tujuan pembelajaran Pendidikan Agama Islam memiliki ciri khas terintegrasi antara kehidupan dunia dan akhirat, sehingga dalam merumuskan perencanaan pembelajaran Pendidikan Agama Islam mestinya harus berbeda dengan mata pelajaran lain. Dalam proses pembelajaran Pendidikan Agama Islam, guru mesti terampil dalam mengembangkan materi dan metode pembelajaran, maka disinilah peran guru mesti memahami kompetensi pedagogik. Ditinjau berdasarkan aspek materi, guru mesti mampu mengembangkan materi Pendidikan Agama Islam bukan hanya dipahami dalam pengetahuan, tetapi materi tersebut harus mampu membuahkan amal perbuatan. Adapun ditinjau berdasarkan aspek metode, guru mesti mulai memberanikan diri menggunakan metode yang berasal dari pendidikan Islam, seperti metode pendidikan Qurani, metode riyadhoh, metode rihlah, metode talaqi, metode halqah dan yang lainnya. Dalam evaluasi pembelajaran, guru hendaknya tidak hanya melihat keberhasilan dari aspek pengetahuan di akhir tanpa melihat proses pembelajaran peserta didik. Dengan demikian, guru mesti menilai aspek sikap dan keterampilan peserta didik sehari-harinya dalam mengamalkan ajaran Islam, karena hakikat tujuan mempelajari Pendidikan Agama Islam untuk mewujudkan peserta didik yang beriman, berilmu, dan beramal.

\section{Ucapan Terima Kasih}

Peneliti mengucapkan terima kasih kepada Prof. Dr. Makhmud Syafe'i, M. Pd., M. Ag. selaku dosen yang telah membimbing dalam penulisan naskah ini. 


\section{Referensi}

Bararah, I. (2017). Efektifitas Perencanaan Pembelajaran Pendidikan Agama Islam Di Sekolah. Jurnal Mudarrisuna, 7(1), 131-147.

Chamanti, A. M. (2013). Pengelolaan Pembelajaran PAI dan Budi Pekerti pada Kurikulum 2013 di Kelas XI-MIA 2 SMA PGII 1 Bandung. Prosiding Penelitian Sivitas Akademika Unisba (Sosial Dan Humaniora), 1-9.

Coombs, P. H. (1982). Apakah Perencanaan Pendidikan Itu? Jakarta: Bhratara Karya Aksara dan UNESCO : Lembaga Internasional untuk Perencanaan Pendidikan.

Fathurrohman, A., \& Nurhadi, M. (2016). Perencanaan Pembelajaran Guru Sekolah Dasar dalam Materi Pendidikan Agama Islam di Kabupaten Pasuruan. Jurnal Ilmu Tarbiyah “At-Tajdid," 5(2), 219-242.

Hidayat, T., \& Asyafah, A. (2018). Paradigma Islam Dalam Metodologi Penelitian dan Implikasinya Terhadap Penelitian Pendidikan Agama Islam. Tadrib, IV(2), 225-245. https://doi.org/https://doi.org/10.19109/tadrib.v4i2.2507

Hidayat, T., \& Asyafah, A. (2019). Konsep Dasar Evaluasi dan Implikasinya Dalam Pembelajaran Pendidikan Agama Islam di Sekolah. Al-Tadzkiyyah: Jurnal Pendidikan Islam, 10(I), 159-181.

Hidayat, T., \& Kosasih, A. (2019). Analisis Peraturan Menteri Pendidikan dan Kebudayaan Republik Indonesia Nomor 22 tahun 2016 Tentang Standar Proses Pendidikan Dasar dan Menengah Serta Implikasinya Dalam Pembelajaran PAI di Sekolah. Murobbi : Jurnal Ilmu Pendidikan, 3(1), 45-69.

Hidayat, T., \& Rahmat, M. (2018). Alternative Actions in Overcoming Learning Difficulties (A Case Study at SMA Negeri 15 Bandung). In Proceeding The 1st International Conference on Islamic Guidance and Counseling (pp. 84-103). Yogyakarta: Department of Islamic Guidance and Counseling Sunan Kalijaga State Islamic University. Retrieved from http://bki.uin-suka.ac.id/id/page/prodi/446Proceeding

Hidayat, T., Rahmat, M., \& Supriadi, U. (2019). Makna Syukur Berdasarkan Kajian Tematik Digital Al-Quran dan Implikasinya dalam Pendidikan Akhlak di Sekolah Dasar. Pendas : Jurnal Ilmiah Pendidikan Dasar, IV(1), 94-110.

Hidayat, T., Rizal, A. S., \& Fahrudin. (2018a). Pendidikan Dalam Perspektif Islam dan Peranannya Dalam Membina Kepribadian Islami. Jurnal Mudarrisuna : Media Kajian 
PERAN GURU DALAM MEWUJUDKAN TUJUAN PEMBELAJARAN PENDIDIKAN AGAMA ISLAM DI SEKOLAH $\begin{array}{lll}\text { Pendidikan } \quad \text { Isama } & \text { 218-244. }\end{array}$ https://doi.org/http://dx.doi.org/10.22373/jm.v8i2.3397 0 Ta

Hidayat, T., Rizal, A. S., \& Fahrudin. (2018b). Peran Pondok Pesantren Sebagai Lembaga Pendidikan Islam di Indonesia. Ta'dib: Jurnal Pendidikan Islam, VII(2), 1-15. Retrieved from https://ejournal.unisba.ac.id/index.php/tadib/article/view/4117/2485

Hidayat, T., \& Suryana, T. (2018). Menggagas Pendidikan Islam : Meluruskan Paradigma Pendidikan di Indonesia. Jurnal Pendidikan Islam Indonesia, 3(1), 75-91. Retrieved from http://ojs.pps-ibrahimy.ac.id/index.php/jpii/article/view/133/93

Hidayat, T., \& Syafe'i, M. (2018). Filsafat Perencanaan dan Implikasinya dalam Perencanaan Pembelajaran Pendidikan Agama Islam di Sekolah. Lentera $\begin{array}{ll}\text { Pendidikan, } & \text { 21(2), 188-205. }\end{array}$ https://doi.org/https://doi.org/10.24252/lp.2018v21n2i5

Hidayat, T., \& Syahidin. (2019). Education Values Based On The Thinking Of KH. Choer Affandi And Their Relevance To The Modern Education (The Study of The Legendary Islamic Scholar of Pondok Pesantren Miftahul Huda Manonjaya, Tasikmalaya). Tadris: Jurnal Pendidikan Islam, 14(1), 27-39.

Hidayat, T., Syahidin, \& Rizal, A. S. (2019). Prinsip Dasar Falsafah Akhlak Omar Mohammad Al - Toumy Al - Syaibany dan Implikasinya dalam Pendidikan di Indonesia. Jurnal Kajian Peradaban Islam, 2(1), 10-17. Retrieved from http://www.jkpis.com/index.php/jkpis/article/view/13/10

Latif, A. (2015). Pendekatan Dalam Pembelajaran Pendidikan Agama Islam (PAI). ElHikmah, 9(1), 43-59.

Rohmah, N. L. (2008). Rencana Pembelajaran Pendidikan Agama Islam dan Implementasinya di SDIT Hidayatullah Yogyakarta. Yogyakarta: Universitas Islam Negeri Sunan Kalijaga.

Sya'idah, U., Amaliyah, \& Ismail, Y. (2016). Kemampuan Guru PAI dalam Merencanakan dan Melaksanakan Penilaian Autentik (Studi Kasus Guru PAI di SMA Negeri 53 Jakarta). Jurnal Studi Al-Qur'an; Membangun Tradisi Berfikir Qur'ani, 12(2), 143157. 